\title{
LESBIAN, GAY, BISEKSUAL, DAN TRANSGENDER PERSPEKTIF AL-QUR'AN DAN HAK ASASI MANUSIA
}

\author{
Oleh: Neny Muthi'atul Awwaliyah ${ }^{1}$
}

\begin{abstract}
LGBT is still a hot polemic in the wider community. Of course we do not want this polemic to be a commotion, an inconvenience and mutual suspicion. The upheaval of thought between the pro and the contra happened around the issue. some of them support it and some are violently rejecting the community. And this caused disputes among scholars, academics, and the wider community. The view of differences in sexual orientation and gender identity outside the relationship between men and women is still very taboo and is still a debate. From the case the author wants to explore more about the LGBT perspective of the United Nations version and the Human Rights.
\end{abstract}

Keywords: LGBT according to the Qur'an, Human Rights

Abstrak: LGBT masih menjadi polemik hangat di masyarakat luas. Tentu kita tidak ingin polemik ini menjadi keributan, ketidaknyamanan dan saling curiga. Pergolakan pemikiran antara yang pro dan yang kontra terjadi seputar isu tersebut. beberapa dari mereka mendukungnya dan beberapa dengan keras menolak komunitas tersebut. Dan hal ini menimbulkan perselisihan di kalangan ulama, akademisi, dan masyarakat luas. Pandangan tentang perbedaan orientasi seksual dan identitas gender di luar hubungan antara laki-laki dan perempuan masih sangat tabu dan masih menjadi perdebatan. Dari kasus tersebut penulis ingin menggali lebih dalam tentang perspektif LGBT versi PBB dan Hak Asasi Manusia.

Kata kunci : LGBT menurut Al-Qur'an, Hak Asasi Manusia

\section{A. Pendahuluan}

Kemunculan komunitas Lesbian, Gay, Biseksual, dan Transgender (LGBT) adalah salah satu hal yang masih hangat dibicarakan dan terus menjadi bahan perdebatan di antara masyarakat Indonesia, diantara mereka ada yang mendukungnya dan ada pula yang dengan keras menolak komunitas tersebut. Masing-masing dari mereka tentu mempunyai argumen sendirisendiri untuk memperkuat pendapat mereka.

\footnotetext{
${ }^{1}$ Neny Muthi'atul Awwaliyah, Mahasiswa Jurusan Aqidah dan Filsafat Islam Konsentrasi Studi Qur'an dan Hadits UIN Sunan Kalijaga Yogyakarta.

Lesbian, Gay, Biseksual, dan Transgender...| 1
} 
Adapun pengertian LGBT sendiri yaitu Lesbian, Gay, Biseksual dan Transgender. Lesbian adalah istilah bagi perempuan yang mengarahkan orientasi seksualnya kepada sesama perempuan, Gay adalah sebuah istilah bagi laki-laki yang umumnya digunakan untuk merujuk orang homoseksual atau sifat-sifat homoseksual, Biseksualitas merupakan ketertarikan romantis, ketertarikan atau kebiasaan seksual kepada pria maupun wanita. Istilah yang digunakan dalam konteks ketertarikan manusia untuk menunjukkan perasaan romantis atau seksual kepada pria maupun wanita sekaligus.

Lesbian dan gay telah mengukir sejarah tersendiri dalam perjalanan umat manusia. Sejarah mengatakan, bahwa seks sesama jenis pada zaman dahulu memang ada dan menjadi salah satu bagian dari pola seks manusia. Berbagai kitab suci seperti al-Qur'an, Injil, dan Taurat telah menjelaskan tentang kaum Nabi Luth A.s. Dalam al-Qur'an sejarah ini diabadikan dalam suratal-A'raf Ayat ke 80-81,

"Dan (kami juga telah mengutus) Luth (kepada kaumnya). (ingatlah) tatkala Dia berkata kepada mereka: "Mengapa kamu mengerjakan perbuatan faahisyah itu, yang belum pernah dikerjakan oleh seorangpun (di dunia ini) sebelummu?"Sesungguhnya kamu mendatangi lelaki untuk melepaskan nafsumu (kepada mereka), bukan kepada wanita, malah kamu ini adalah kaum yang melampaui batas. "

Seperti yang kita tahu kebutuhan seks adalah fitrah setiap manusia, baik laki-laki maupun perempuan. Dan setiap laki-laki maupun perempuan mempunyai hak untuk memenuhi kebutuhan tersebut. Akan tetapi, seksual yang menjadi fitrah setiap manusia ini sering disalahgunakan. Dan ini menyebabkan perselisihan di kalangan ulama, akademisi, dan masyarakat luas. Pandangan terhadap perbedaan orientasi seksual dan identitas gender diluar hubungan antara laki-laki dengan perempuan masih sangat tabu dan masih menjadi perdebatan. Persoalan perbedaan orientasi seksual merupakan hak setiap manusia. $^{2}$

Ada banyak prinsip, aturan bahkan undang-undang yang mengatur tentang HAM, dan ini merupakan suatu landasan kuat yang dipegang teguh oleh komunitas LGBT untuk tetap mempertahankan keberadaannya di masyarakat. Akan tetapi, keberadaan kaum homoseks atau gay ditengah masyarakat mendapat tanggapan yang berbeda, begitu juga dalam pandangan agama. Ada sebagian tokoh agama yang tergolong dalam legal oriented people, kelompok ini berusaha untuk menerima dan menghargai pilihan

${ }^{2}$ Rido Triawan, Jalan Panjang Mencari Keadilan Bagi Kelompok LGBT, (Jakarta: Arus Pelangi, 2008), hlm. 6.

2 | Neny Muthi'atul Awwaliyah 
orientasi kaum gay, karena ini merupakan bagian hak asasi manusia, tetapi juga mendapat perlawanan dari tokoh agama salaf sholih yang menyatakan bahwa kaum homoseksual adalah kaum yang menyalahi fitrah penciptaan manusia, homoseksual merupakan perbuatan keji dan terlaknat dan merusak agama, kehormatan dan moral masyarakat.

Masyarakat Indonesia merupakan masyarakat yang masih memegang nilai-nilai keagamaan sebagai basis dalam masyarakat, maka pandangan masyarakat Indonesia tidak bisa terlepasdari norma-norma dan nilai keagamaan yang mereka yakini. Pemahaman agama Islam yang secara umum mengatakan bahwa perilaku maupun orientasi homoseksual merupakan perbuatan keji dan terlaknat. Seperti yang kita ketahui, mayoritas masyarakat Indonesia adalah masyarakat muslim yang berpegang teguh pada syari'at, dan sumber syari'at umat muslim adalah al-Qur'an. Dari pernyataan dan fenomena yang telah dipaparkan diatas, penulis ingin meneliti suatu yang menarik, yakni LGBT perspektif al-Qur'an dan HAM versi PBB.

\section{B. Sejarah LGBT dalam Al-Qur'an}

Jika kita mencari kata homoseks atau LGBT dalam al-Qur'an, tentunya tidak akan ditemui karena perkataan tersebut merupakan istilah baru yang dikenal pada akhir abad ke-19. Tetapi kewujudan golongan LGBT bukanlah hal yang baru. Dalam al-Qur'an sendiri telah diceritakan, bahwa golongan ini telah mulai ada sejak sebelum Masehi yaitu di zaman Nabi Luth A.s Kaum Nabi Luth A.s adalah golongan manusia pertama yang menjadi pemicu terjadinya perbuatan tercela homoseks yang sebelumnya tidak pernah dilakukan oleh siapa pun dari keturunan Nabi Adam A.s Firman Allah surat Al-A'raf ayat 80-82,

Dan (kami juga telah mengutus) Luth (kepada kaumnya). (ingatlah) tatkala Dia berkata kepada mereka: "Mengapa kamu mengerjakan perbuatan faahisyah itu, yang belum pernah dikerjakan oleh seorangpun (di dunia ini) sebeluтти?"Sesungguhnya kamu mendatangi lelaki untuk melepaskan nafsumu (kepada mereka), bukan kepada wanita, malah kamu ini adalah kaum yang melampaui batas. jawab kaumnya tidak lain hanya mengatakan: "Usirlah mereka (Luth dan pengikut-pengikutnya) dari kotamu ini; Sesungguhnya mereka adalah orang-orang yang berpura-pura mensucikan diri."

Kaum Nabi Luth yang ketika itu menetap di Kota Sadom merupakan kaum yang rusak akhlaknya kerana melakukan hubungan sejenis, meliwat dan menikahi kaum sejenis mereka. Lebih dalamnya dijelaskan bahwa penduduk negeri Sodom atau kaum Nabi Luth mempraktikkan perilaku menyimpang Lesbian, Gay, Biseksual, dan Transgender... |3 
yakni sodomi. Seorang laki-laki tidak mau menikah atau kawin dengan perempuan, tetapi mereka menghendaki sejenisnya (laki-laki menikah dengan laki-laki). Selain itu, mereka juga suka merampok para musafir atau kafilah yang sedang lewat.

Dalam al-Qur'an, Allah Swt. merekamkan sejarah perilaku kaum Nabi Luth secara lengkap dalam beberapa ayat dan surah. Beliau (Nabi Luth) diutus Allah ke negeri Sadom, suatu negeri yang penduduknya sangat durhaka kepada Allah. Budi pekerti mereka sangat rendah dan hina sekali. Mereka itu adalah manusia yang tidak tahu malu, bahkan tidak suka diberi nasihat. Ketika mereka diberi nasihat dan dipertakuti dengan siksaan Allah Swt, mereka menjawab: "Datangkanlah siksaan Allah itu, hai Luth, jika sekiranya kamu orang yang benar". Firman Allah Swt. dalam al-Qur'an surat Al-Ankabut ayat 28-29, Datangkanlah kepada Kami azab Allah, jika kamu termasuk orangorang yang benar". Nabi Luth berulang kali menyeru kaumnya kepada sebuah kebenaran yang begitu nyata, dan memperingatkan mereka dengan jelas, namun kaumnya sama sekali tidak mengindahkan peringatan apapun dan terus menolak ajakan beliau. Bahkan mereka menentang agar agar adzab Allah segera diturunkan. Dikarenakan menerima jawaban demikian dari kaumnya, nabi Luth pun meminta pertolongan Allah Swt, seperti yang telah tertulis dalam al-Qur'an surat Al-'Ankabut ayat 30, surat Asy-Syu'ara ayat 169.

Setelah meninggalkan Nabi Ibrahim para malaikat yang dikirim sebagai utusan lalu mendatangi Nabi Luth. Para utusan mengabarkan bahwa kaum Nabi Luth yang durjana itu, termasuk istri Nabi Luth yang tidak mau beriman, akan ditumpas habis di waktu shubuh. Mereka meminta Nabi Luth mengajak pengikutnya yang beriman untuk segera menyingkir dari kota itu akhir malam.

Sementara itu, kaum Nabi Luth telah mengetahui bahwa beliau kedatangan tamu. Mereka tidak ragu-ragu untuk mendatangi tamu-tamu tersebut dengan niat buruk. Mereka mengepung rumah Nabi Luth, dan membujuk beliau agar menyerahkan tamu-tamunya. Namun kemudian Allah membutakan mata mereka, sebagaimana firman Allah surat Al-Qomar ayat 37-38.

Sebagai usaha menyadarkan mereka, peringatan-peringatan lisan telah beliau (Nabi Luth) lakukan. Bahkan, Nabi Luth bersedia menyediakan putriputrinya kepada mereka untuk dinikahi, sebagaimana manusia normal. Tapi, usaha yang beliau tempuh ini jadi sia-sia ketika mereka menolak tawaran beliau, bahkan mencaci-maki dia beserta keluarga dan kaumnya yang taat, serta diusir dari kampung halaman. Kisah ini terekam dalam al-Qur'an pada 
surah Hud ayat 79,

"'Mereka menjawab: "Sesungguhnya kamu telah tahu bahwa Kami tidak mempunyai keinginan terhadap puteri-puterimu; dan Sesungguhnya kamu tentu mengetahui apa yang sebenarnya Kami kehendaki." Juga dalam surat al-A'raaf ayat 82 yang artinya: jawab kaumnya tidak lain hanya mengatakan: "Usirlah mereka (Luth dan pengikut-pengikutnya) dari kotamu ini; Sesungguhnya mereka adalah orang-orang yang berpura-pura mensucikan diri."

Itulah satu kisah sejarah bangsa Sodom yang melakukan perilaku seks songsang pertama di bumi. Rekaman sejarah tersebut, menjadi bukti bahwa homoseksual adalah bagian dari penyakit sosial yang dibenci oleh Allah dan para Nabi. Di sini jelas bahwa golongan ini telah ada sejak dari zaman dulu.

\section{Penafsiran Ayat Tentang Lesbian Gay Biseksual Transgender}

Dalam memahami ayat di atas penulis akan membandingkan penafsiran antara tafsir Ibnu Katsir dengan al-Misbah yang menjelaskan tentang Nabi Luth dan kaumnya (sodomi). Dalam tafsir Ibnu Katsir dijelaskan bahwa Allah mengutus Nabi Luth kepada penduduk kampung Sodom dan sekitarnya, guna menyeru kepada mereka untuk beribadah kepada Allah Swt, berbuat amar ma'ruf nahi munkar, serta hal-hal yang haram dan keji, yang dosa tersebut tidak pernah dilakukan oleh seorang pun dari anak cucu Adam sebelumnya, yaitu mendatangi lelaki (untuk melampiaskan nafsu birahi), bukan kepada wanita.

Homoseks seperti ini pertama kali dilakukan oleh penduduk Sodom laknatullah. Amru bin Dinar memberikan argumentasi tentang firman Allah, "(Dosa) yang belum pernah dikerjakan oleh seorangpun (di dunia ini) sebelummu...." Beliau berkata, "Belum pernah ada lelaki yang menjantani sesamanya sebelum kaum Nabi Luth A.s. Sedangkan komentar yang dilontarkan oleh Walid bin Abdul Malik adalah, "Sekiranya Allah tidak menceritakan berita tentang kaum Nabi Luth kepada kita, maka kita tidak akan tahu bahwa ada lelaki "menaiki" sesama lelaki. ${ }^{3}$ Dalam hal ini Nabi Luth berkata kepada mereka (surat Al-A'raf ayat 80-81),

"Mengapa kamu mengerjakan perbuatan faahisyah itu, yang belum pernah dikerjakan oleh seorangpun (di dunia ini) sebelummu?' Sesungguhnya kamu mendatangi lelaki untuk melepaskan nafsumu (kepada mereka), bukan kepada wanita, malah kamu ini adalah kaum yang melampaui batas.'

${ }^{3}$ Beliau adalah Seorang Khalifah Dinasti Bani Umayyah kedua, sekaligus pendiri Masjid Jami’ Damaskus.

Lesbian, Gay, Biseksual, dan Transgender... $\mid 5$ 
Apakah kalian telah berlaku adil kepada wanita, padahal mereka diciptakan oleh Tuhan untuk kaum laki-laki? Kalian telah keterlaluan dan bodoh sebab telah meletakkan sesuatu bukan pada tempatnya.Oleh karena itu, pada ayat lain Nabi Luth berkata, "inilah putri-putriku, jika kalian hendak berbuat (secara yang halal). ${ }^{4}$

Sedangkan menurut tafsir al-Misbah Yakni kisah Nabi Luth A.s, Anda boleh bertanya mengapa bukan kisah Nabi Ibrahim A.s yang kedudukannya jauh lebih tinggi dari Nabi Luth A.s. Di sisi lain bukankah beliau semasa dengan Nabi Luth A.s agaknya hal tersebut disebabkan karena surah ini bermaksud memaparkan kisah umat nabi-nabi yang durhaka dan dijatuhi sanksi oleh Allah swt. Umat Nabi Ibrahim A.s Tidak dijatuhi hukuman oleh Allah, karena beliau tidak memohon jatuhnya sanksi terhadap mereka tetapi beliau meninggalkan mereka berhijrah ke tempat lain. Ayat di atas menyatakan:

Dan Kami juga mengutus Nabi Luth. Ingatlah ketika dia berkata kepada kaumnya yang ketika itu melakukan kedurhakaan besar: Apakah kamu mengerjakan fahisyah yakni melakukan pekerjaan yang sangat buruk yaitu anal seks yang tidak satupun mendahului kamu mengerjakanya di alam raya, yakni di kalangan mahkluk hidup di dunia ini. Sesungguhnga kamu telah mendatangi lelaki untuk melampiaskan syahwat (nafsu) kamu melalui mereka sesama jenis kamu, bukan terhadap wanita yang secara naluriah seharusnya kepada merekalah kamu menyalurkan naluri seksual. Hal itu kamu lakukan terhadap lelaki bukan disebabkan karena wanita tidak ada atau tidak mencukupi kamu, tetapi itu kamu lakukan karena kamu durhaka bahkan kamu adalah kaum yang melampaui batas sehingga melakukan pelampiasan syahwat bukan pada tempatnya. ${ }^{5}$

Menurut Quraish Shihab ayat ini tidak menyebut Nabi Luth A.s sebagai saudara mereka sebagaimana halnya Nabi Hud, Shaleh dan Syu'aib A.s Ketika menguraikan kisah ketiga nabi yang disebut terakhir, al-Qur'an menyatakan bahwa: dan kepada 'Ad saudara mereka Hud. Demikian juga dan kepada Tsamud saudara mereka Shaleh dan kepada Madyan saudara mereka Syu'aib. Ketiadaan penyebutan kata saudara buat Nabi Luth AS untuk mengisyaratkan bahwa beliau bukanlah dari suku masyarakat yang beliau diutus menghadapinya. Nabi Luth A.s bersama Nabi Ibrahim A.s adalah pendatang di

${ }^{4}$ Ibnu Katsir, Tafsir Al Qur'an Al 'Adzim, (Istambul: Dar Dakwah), jilid II, hlm. 230.

${ }_{5}$ M.Quraish Shihab, Tafsir al-Mishbah, Pesan, Kesan dan Keserasian al-Qur'an, (Jakarta: Lentera Hati, 2005),Vol. 5, hlm.159-160.

6| Neny Muthi'atul Awwaliyah 
kota itu setelah berhijrah dari Harran (Carrahae). Beliau berasal dari daerah Kan'an, satu daerah yang terletak dibagian barat Palestina dan Suriah sekarang. Itu pula salah satu sebab mengapa ayat yang berbicara tentang pengutusan Nabi Luth A.s tidak menyatakan bahwa beliau saudara mereka. Bahwa Nabi Luth A.s Diutus kepada kaumnya karena seseorang yang bertempat lama pada satu tempat dapat dinilai sebagai salah seorang anggota kaum masyarakat itu.

Ayat di atas tidak menyebut nama kaum Luth itu, sebagaimana ayat-ayat yang menyebut nama kaum Nabi Hud, Shaleh, dan Syu'aib seperti 'Ad, Tsamud, dan Madyan. Hal tersebut sebagai pengajaran kepada umat Islam agar merahasiakan nama pelaku kejahatan, dalam hal-hal tertentu di mana penyebutan nama tidak diperlukan, apalagi jika kejahatan yang mereka lakukan adalah sesuatu yang sangat buruk atau dapat merangsang orang lain melakukannya. Tidak satu ayat pun yang menyebut nama kaum Luth, berbeda dengan nabi-nabi yang lain. Memang, Nabi Nuh A.s pun tidak disebut nama kaumnya, karena ketika itu, umat manusia belum berpencar baik tempat tinggalnya maupun suku-suku bangsanya.

Menurut Quraish Shihab, Nabi Luth A.s dalam ayat ini sedikit berbeda dengan nabi-nabi yang disebut sebelumnya. Beliau tidak berpesan tentang tauhid atau penyembahan Tuhan Yang Maha Esa. Beliau tidak berkata sebagaimana nabi-nabi sebelumnya: Wahai kaumku sembahlah Allah tidak ada bagi kamu satu Tuhanpun selain-Nya. Ini bukan berarti bahwa beliau tidak mengajak mereka kepada tauhid, tetapi ada sesuatu yang sangat buruk yang hendak beliau luruskan bersama pelurusan aqidah mereka yaitu kebiasaan buruk mereka dalam bidang seks. Di sisi lain perlu diingat bahwa penekanan tentang keburukan tersebut tidaklah jauh dari persoalan aqidah, ketuhanan dan tauhid. Karena keduanya adalah fitrah. Syirik adalah pelanggaran terhadap fitrah, anal seks pun merupakan pelanggaran fitrah. Allah Yang Maha Esa itu telah menciptakan manusia bahkan makhluk memiliki kecenderungan kepada lawan jenisnya, dalam rangka memelihara kelanjutan jenisnya.

Kenikmatan yang diperoleh dari hubungan tersebut bersumber dari lubuk hati masing-masing pasangan bukan hanya kenikmatan jasmani, tetapi kenikmatan rohani dan gabungan kenikmatan dari dua sisi itulah yang menjadi jaminan sekaligus dorongan bagi masing-masing untuk memelihara jenis dan sebagai imbalan kewajiban dan tanggung jawab memelihara anak keturunan. Mereka yang melakukan anal seks hanya mengharapkan kenikmatan jasmani yang menjijikkan sambil melepaskan tanggung jawabnya. Ini belum lagi 
dampak negatif terhadap kesehatan jasmani dan rohani yang diakibatkannya. ${ }^{6}$

Menurut Quraish Shihab hubungan seks yang merupakan fitrah manusia hanya dibenarkan terhadap lawan jenis. Pria mencintai dan birahi terhadap wanita demikian pula sebaliknya. Selanjutnya fitrah wanita adalah monogami, karena itu, poliandri (menikah/berhubungan seks pada saat sama dengan banyak lelaki) merupakan pelanggaran fitrah wanita, berbeda dengan lelaki yang bersifat poligami, sehingga buat mereka poligami dalam batas dan syarat-syarat tertentu tidak dilarang agama. Kalau wanita melakukan poliandri atau lelaki melakukan hubungan seks dengan wanita yang berhubungan seks dengan lelaki lain, atau terjadi homoseksual baik antara lelaki dengan lelaki maupun wanita dengan wanita, maka itu bertentangan dengan fitrah manusia. Setiap pelanggaran terhadap fitrah mengakibatkan apa yang diistilahkan dengan uqubatul fithrah (sanksi fitrah).

Dalam konteks pelanggaran terhadap fitrah seksual, sanksinya antara lain apa yang dikenal dewasa ini dengan penyakit Aids. Penyakit ini pertama kali ditemukan di New York Amerika Serikat pada 1979 pada seorang yang ternyata melakukan hubungan seksual secara tidak normal. Kemudian ditemukan pada orang-orang lain dengan kebiasaan seksual serupa. Penyebab utama Aids adalah hubungan yang tidak normal itu, dan inilah antara lain yang disebut fahisyah di dalam al-Qur'an. Dalam satu riwayat yang oleh sementara ulama dinyatakan sebagai hadits Nabi Muhammad Saw. dinyatakan bahwa: "Tidak merajalela fahisyah dalam satu masyarakat sampai mereka terangterangan melakukannya kecuali tersebar pula wabah dan penyakit diantara mereka yang belum pernah dikenal oleh generasi terdahulu." Pelampauan batas yang menjadi penutup ayat ini mengisyaratkan bahwa kelakuan kaum Nabi Luth A.s itu melampaui batas fitrah kemanusiaan, sekaligus menyia-nyiakan potensi mereka yang seharusnya ditempatkan pada tempatnya yang wajar, guna kelanjutan jenis manusia. ${ }^{7}$

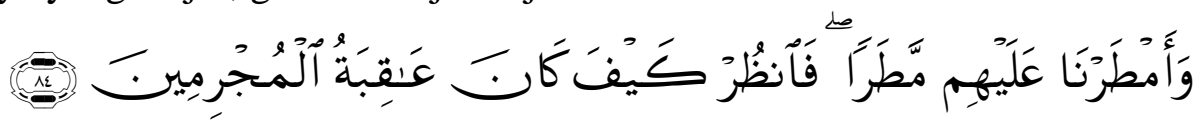

"Dan Kami turunkan kepada mereka hujan (batu); Maka perhatikanlah bagaimana kesudahan orang-orang yang berdosa itu. ${ }^{8}$

Setelah menjelaskan keselamatan Nabi Luth A.s dan pengikut-pengikut beliau dan mengisyaratkan jatuhnya siksa bagi yang membangkang, ayat ini

${ }^{6}$ M.Quraish Shihab,...hlm. 161-162.

${ }^{7}$ M.Quraish Shihab,...hlm. 161-162.

${ }^{8}$ QS. Al-A'raf ayat 84.

8| Neny Muthi'atul Awwaliyah 
menurut Quraish Shihab menjelaskan jenis siksaan yang menimpa mereka dengan menyatakan: Dan Kami hujani, yakni kami turunkan dari langit sehingga mengenai bagian atasmereka, bukan di samping mereka hujan batu yang akhirnya membinasakan mereka maka lihatlah bagaimana kesudahan para pendurhaka termasuk mereka itu. Firman-Nya: (عَلَّْْر ) 'alaihim/atasmereka mengisyaratkan bahwa siksa tersebut tidak dapat mereka elakkan, karena ia datang dari arah atas. Biasanya yang berada di atas mengontrol dan menguasai secara penuh yang berada di bawah. Sementara ulama memahami dari penggunaan bentuk nakirah/indefinite terhadap kata ( matharan/hujan sebagai isyarat bahwa hujan dimaksud adalah sesuatu yang luar biasa dan ajaib. Hujan tersebut dijelaskan oleh Q.s. Hud: 82-83:

"Maka tatkala datang azab Kami, Kami jadikan negeri kaum Luth itu yang di atas ke bawah (kami balikkan), dan Kami hujani mereka dengan batu dari tanah yang terbakar dengan bertubi-tubi, 83. yang diberi tanda oleh Tuhanmu, dan siksaan itu Tiadalah jauh dari orang-orang yang zalim. ${ }^{9}$

Homoseks dalam Masyarakat Modern, Kendati kaum Nabi Luth telah dihancurkan oleh Allah ratusan abad yang lalu, namun homoseks tetap ada di tengah kehidupan manusia. Siksaan keras yang ditimpakan kepada kaum Luth tidaklah diambil sebagai pelajaran. Bahkan dunia dewasa ini dilanda revolusi seks yang jauh melampaui batasdan ketentuan agama. George Harvard dalam bukunya Revolusi Seks mengungkapkan, "Kita tidak begitu khawatir terhadap bahaya nuklir yang mengancam kehidupan manusia di abad modern ini. Yang kita khawatirkan adalah serangan bom seks yang setiap saat dapat meledak, menghancurkan moral manusia."Pandangan semacam ini juga dilontarkan oleh sejarawan Arnold Toynbee yang menyatakan, "Dominasi seks dewasa ini akan mengakibatkan runtuhnya peradaban manusia." 10

Pernyataan para ahli ini didasarkan atas fakta empiris bahwa huhungan seks dewasa ini tidak lagi terbatas pada suami istri atau dua insan berlainan jenis, tetapi telah jauh melebar ke bentuk hubungan seks sesama jenis, baik homoseks maupun lesbian. Inilah yang melatarbelakangi tulisan James Ruston diharian New York Times yang menyatakan bahwa bahaya tenaga seks lebih besar daripada bahaya tenaga nuklir. Ini dapat dibuktikan dari catatan resmi

\footnotetext{
${ }^{9}$ Yakni orang-orang zalim itu karena kezalimannya, mereka pasti mendapat siksa yang demikian. Adapula sebagian mufassir mengartikan bahwa negeri kaum Luth yang dibinasakan itu tidak jauh dari negeri Mekah.

${ }^{10}$ Fathi Yakan, al-Islam wa al-Jins, penerj. Syafril Halim, Islam dan Seks (Jakarta: Al-Hidayah, 1989), hlm. 78.
} 
Dewan Kesehatan Dunia, bahwa terdapat puluhan juta orang melakukan homoseks, tiga juta orang di antaranya di Amerika. ${ }^{11}$ Penyimpangan seksual itu bukan hanya dilakukan oleh orang-orang ateis yang menyangkal wujud Allah dan menentang. Hari Kebangkitan, melainkan juga dilakukan orang beragama, yang meyakini adanya Tuhan dan alam akhirat. Ini disebabkan peradaban manusia dewasa ini telah jauh mengarah kematerialisme, meninggalkan agama dan nilai spiritual. Pada masyarakat kota telah tersebar berbagai sarana pembangkit api syahwat serta naluri-naluri hewaniah. ${ }^{12}$ Orang-orang yang melakukan penyimpangan seksual, dan menenggelamkan dirinya dalam kelezatan syahwat, akan pudar perasaan agamanya, dan semakin jauh. Dinyatakan oleh al-Qur'an, bila hati manusia telah bergelimang dengan dosa, maka iman yang berada dalam kalbunya akan memudar, dan tidak akan dapat menerima hidayah Tuhan.

Pengaruh penyimpangan seks semacam homoseksual, menurut ahli ilmu jiwa, adalah tidak adanya keinginan melangsungkan perkawinan. Jika ada di antaranya yang telah kawin, akan menyuruh laki-laki yang disukainya untuk menyetubuhi istrinya sendiri asalkan laki-laki itu bersedia digaulinya secara homoseks. Bila seorang homo telah berusia lanjut dan tidak sanggup mendatangi laki-laki, dia sendiri yang mengundang, dan membayar sejumlah uang sebagai imbalan. Akibat dari perilaku ini perempuan pun merasa tidak puas bersetubuh dengan laki-laki, dan timbullah keinginan mereka untuk melakukan hubungan seks antar sesamanya (lesbian). ${ }^{13}$ Menurut Muhammad Rashfi dalam kitabnya al-Islam waal-Tib, sebagaimana dikutib oleh Sayyid Sabiq, bahwa Islam melarang keras homoseks, karena mempunyai dampak yang negatif terhadap kehidupan pribadi dan masyarakat, antara lain: ${ }^{14}$ a.Seorang homo tidak mempunyai keinginan terhadap wanita.

Jika mereka melangsungkan perkawinan, sang istri tidak akan mendapatkan kepuasan biologis, karena nafsu berahi suami telah tertumpah ketika melangsungkan homoseks terhadap laki-laki yang diinginkannya. Akibatnya, hubungan suami-istri menjadi renggang, tidak tumbuh rasa cinta dan kasih sayang, dan tidak memperoleh keturunan, sekalipun istrinya subur dan dapat melahirkan. b. perasaan cinta dengan sesama jenis membawa kelainan jiwa yang menimbulkan suatu sikap dan perilaku ganjil. Seorang

\footnotetext{
${ }^{11}$ Fathi Yakan,... hlm. 49

${ }^{12}$ Murtadha Mutahhari, Manusia dan Agama (Bandung: Mizan, 1984), hlm. 58.

${ }^{13}$ Hamka, Tafsir al-Azhar (Jakarta: PanjimAS, 1979), hlm. 290.

${ }^{14}$ Sayyid Sabiq, Fiqh al-Sunnah, VI, hlm 361-365.
} 
homo kadang-kadang berperilaku sebagai laki-laki dan kadang-kadang sebagai perempuan. c. Mengakibatkan rusaknya saraf otak, melemahkan akal, dan menghilangkan semangat kerja.

Di samping akibat negatif di atas, ada pula akibat yang sangat membahayakan bagi kelangsungan hidup seseorang, yakni berjangkitnya penyakit Aids. Penyakit Aids yang menyebar ke berbagai penjuru dunia cukup menggetarkan para pelaku penyimpangan seks, karena kedokteran masih sulit menemukan obat untuk menyembuhkan penderitanya. Penderita Aids akan kehilangan daya ketahanan tubuhnya, akibat serangan bakteri yang menggerogoti pembuluh darah, kulit, tubuh, dan alat kelamin. Korban penyakit Aids telah banyak, terutama di Eropa dan Amerika Serikat. Hasil survei di Amerika Serikat tahun 1985 ditemui 12.000 penderita Aids. Dari jumlah ini $73 \%$ akibathubungan free sex, terutama homoseks, $17 \%$ akibat penyalahgunaan obat narkotik atau sejenisnya, dan 2,5\% akibat transfusi darah. ${ }^{15}$ Selain penyakit Aids ada pula penyakit kelamin lainnya,yaitu sipilis. Menurut seorang ahli medis Prancis, di Prancis setiap tahunnya ada 30.000 orang meninggal karena penyakit ini. Sementara itu, di Amerika terdapat sekitar 30.000 sampai 40.000 orang meninggal. Menurut para ahli, penyakit ini menular dengan hubungan seksual, seperti zina, homoseks, dan lesbian. Kuman sipilis berkembang biak melalui luka, yang menular dengan cepat. Penyakit ini sangat berbahaya, penderitanya dapat menjadi lumpuh karena lemahnya daya tahan tubuh, dan membawa kematian. ${ }^{16}$

Di samping bahaya bagi individu pelakunya, homoseks juga membahayakan masyarakat. Jika individu enggan menikah, dan melampiaskan nafsu seksnya secara tidak legal, dengan sendirinya merusak sistem kekeluargaan dan merapuhkan landasan kemasyarakatan. Selanjutnya menimbulkan kehancuran akhlak, dan merenggangkan ikatan nilai-nilai dan norma agama yang akhirnya membawa kebebasantanpa batas, seperti yang kita saksikan dalam masyarakat dewasa ini. ${ }^{17}$ Untuk menghindari akibat negatif homoseks, diperlukan pembinaan akhlak yang sesuai norma dan nilainilai agama. Dan pembentukan akhlak yang benar merupakan utopia selama prinsip dan sistem yang berlaku bersifat materialistis yang bertentangan dengan prinsip dan sistem agama.

\footnotetext{
${ }^{15}$ Masfuk Zuhdi, Masail Fiqhiyah, (Jakarta: Karya Unipress, 1988), hlm. 39.

${ }^{16}$ Baca Ramlan Yusuf Rangkuti: Homoseksual Jurnal Ilmu Syari'ah dan Hukum Vol. 46 No. I, Januari-Juni 2012, hlm. 199.

${ }^{17}$ Sayyid Syabiq,... hlm. 431.
} 
Hilangnya rasa keagamaan dalam kehidupan masyarakat dan berjayanya hukum-hukum dari teori materialisme merupakan faktor yang menyebabkan penyimpangan seks. Para pemuka agama dan ahli medis berusaha keras menanggulangi dan mencegah penyimpangan seks. Di Swedia pada April 1964, terdapat 140 orang dokter ahli mengajukan memorandum kepada parlemen untuk segera mengatasi kekacauan seks, yang mengancam kesehatan dan kestabilan masyarakat. Hal yang sama juga dilakukan di Inggris tahun 1976, terutama dari kaum wanita, yang menuntut agar pemerintah meluruskan akhlak masyarakat. Tuntutan ini mendapat respons dari penguasa, namun pemerintah tidak mampu membendung penyimpangan seks karena keadaannya sudah demikian parah, yang berakar dari terlepasnya nilai-nilai serta norma agama dalam seluruh aspek kehidupan masyarakat. ${ }^{18}$

\section{Lesbian, Gay, Biseksual dan Trangender dalam Islam}

\section{Homoseksual}

Dalam Islam istilah homoseksual di kenal dengan kata liwath. Liwath dari kata لاط - ليط -لوطا ( laatha- yaliithu-lauthan) yang berarti melekat. Sedang liwath adalah orang yang melakukan perbutannya kaum Nabi Luth atau dari kata لاوط - يلاوط (laawatha- yulaawithu) yang berarti orang yang melakukan perbuatan kaum Nabi Luth (hubungan sejenis). ${ }^{19}$

Menurut istilah Liwath atau Homoseksual adalah suatu keinginan membina hubungan romantis atau hasrat sosial kepada sesama jenis, jika sesama pria dinamakan gay dan sesama wanita dinamakan lesbian (female homosex). ${ }^{20}$ Homoseks merupakan penyimpangan dari fitrah manusia karena secara fitrah manusia cenderung untuk melakukan hubungan biologis secara heteroseks, yaitu hubungan seks antara wanita dan pria. Homoseks merupakan salah satu bentuk kelainan seksual atau tidak normal.

Secara gramatikal (bahasa) tidak ada perbedaan penggunaan kata antara homoseksual dan lesbian. Dalam bahasa arab kedua- duanya dinamakan alLiwath. Pelakunya dinamakan al-Luthiy (lotte). Namun Imam al- Mawardi membedakannya. Beliau menyebut homoseksual dengan liwath dan lesbian

${ }^{18}$ Fathi Yakan,... hlm. 10-14.

${ }^{19}$ http://islamind.blogspot.com/2011/12/hukuman-pelaku-liwath-sodomi_17. diakses pada 2 Agustus 202013.00 WIB

${ }^{20}$ Hasbiyatlah, Masail Fiqhiyah, (Jakarta:DirJen Pendidikan Islam, Depag Republik Indonesia, 2009), hlm. 287 
dengan sihaq atau musaahaqah. ${ }^{21}$

\section{Transgender atau Taghyir al-Jins}

Pada dasarnya Allah SWT menciptakan manusia terdiri dari 2 macam jenis kelamin yaitu laki-laki dan perempuan. Sebagaimana telah dituturkan dalam Al Qur'an surat Al Hujurat ayat 13 sebagai berikut:

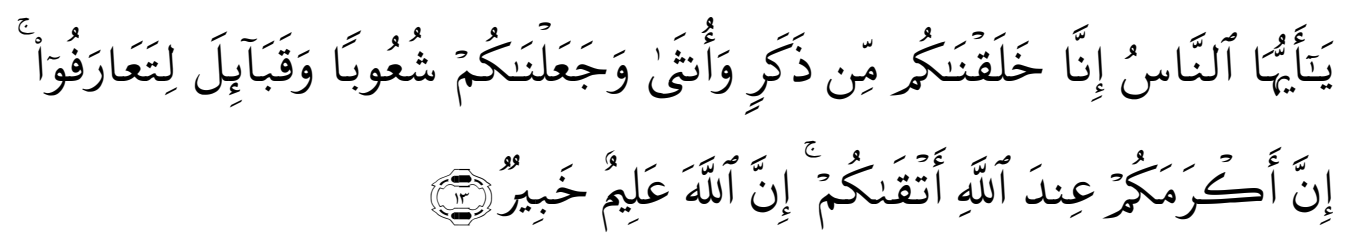

" Hai manusia, sesungguhnya Kami menciptakan kamu dari seorang laki-laki dan seorang perempuan dan menjadikan kamu berbangsa - bangsa dan bersuku-suku supaya kamu saling kenal-mengenal. Sesungguhnya orang yang paling mulia diantara kamu disisi Allah ialah orang yang paling taqwa diantara kamu. Sesungguhnya Allah Maha Mengetahui lagi Maha Mengenal."

Jika berbicara kelamin berarti ini berkaitan dengan gender beserta alat reproduksinya. Perspektif gender dalam al-Qur'an tidak sekedar mengatur keserasian relasi gender, hubungan laki-laki dan perempuan dalam masyarakat tetapi lebih dari itu al-Qur'an juga mengatur keserasian pola relasi antara mikrokosmos (manusia), makrokosmos (alam), dan Tuhan.

Secara umum al-Qur'an mengakui adanya perbedaan antara laki-laki dan perempuan, tetapi perbedaan tersebut bukanlah diskriminasi yang menguntungkan satu pihak dan yang lain dirugikan. Perbedaaan tersebut dimaksudkan untuk mendukung obsesi al-Qur'an, yaitu terciptanya hubungan harmonis yang didasari rasa kasih sayang di lingkungan keluarga. Sebagaimana telah dituturkan dalam al-Qur'an surat Ar-Rum: 21 sebagai berikut:

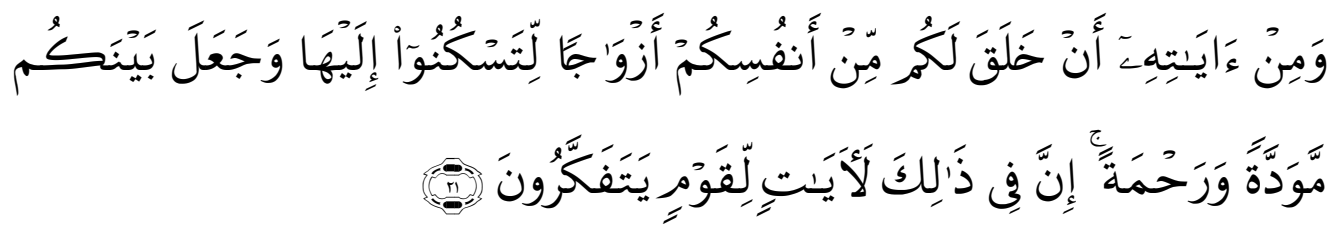

"Dan di antara tanda-tanda kekuasaan-Nya ialah Dia menciptakan untukmu isteri-isteri dari jenismu sendiri, supaya kamu cenderung dan merasa tenteram kepadanya, dan dijadikan-Nya diantaramu rasa kasih dan sayang. Sesungguhnya pada yang demikian itu benar-benar terdapat tanda-

\footnotetext{
${ }^{21}$ Hasbiyatlah, Masail... hlm. 289.
}

Lesbian, Gay, Biseksual, dan Transgender... | 13 
tanda bagi kaum yang berfikir."

\section{E. Lesbian, Gay, Biseksual dan Trangender Perspektif HAM}

Mungkin bagi sebagian orang yang pro dengan LGBT menuntut agar pemerintah melegalkan perbuatan tersebut. Mereka sering berdalih dengan landasan hak asasi manusia (HAM) sebagai tameng utamanya. Bahkan Indonesia sebagai salah satu negara hukum memberikan jaminan kebebasan berekspresi diatur dalam UUD 1945 amandemen II, yaitu pasal 28 E ayat (2) yang menyatakan: "setiap orang berhak atas kebebasan meyakini kepercayaan, menyatakan pikiran dan sikap sesuai dengan hati nuraninya". Setidaknya tidak kurang dari Sembilan pasal yang terdapat pada Deklarasi Universal Hak-Hak Asasi Manusia (DUHAM) yang diumumkan oleh Majelis Umum PBB pada tanggal 10 Desember 1948 melalui resolusi 217 A (III), Dari pasal tersebut, dapat dimengerti bahwa kaum minoritas LGBT ini mendapatkan hak yang sama dengan kaum mayoritas atau heteroseksual.

Dari sini, penulis tidak ingin menyatakan pandangan ini benar. Apakah problem kejiwaan/problem sosial atau bukan, kita semua dituntut agar memahaminya dengan baik dan segera dicari solusinya. Sekalipun mereka masih tetap teguh kepada pendirianya untuk melegalkan perbuatan ini. Maka hal yang harus dijadikan basis fundamental dan harus selalu diingat dalam kaitanya penegakkan hak asasi manusia adalah bahwa HAM berbanding lurus dengan kewajiban- kewajiban yang harus dilakukan. Dengan demikian, setiap individu bebas dan berhak atas haknya masing-masing, namun pada saat yang sama ia harus memperhatikan hak-hak orang lain yang berada di lingkungannya. Sejauh pengamatan penulis sampai saat ini, pandangan kelompok ini baru sampai pada taraf menuntut hak-haknya saja.

\section{F. Kesimpulan}

Dari pembahasan tersebut dapat disimpulkan beberapa poin utama sebagai berikut : Lesbian, Gay, Biseksual dan Transgender, bukanlah fenomena baru yang muncul diduia sekarang ini, karena telah didokumentasikan dalam al-Qur'an, bahwa zaman dahulu tepatnya pada zaman Nabi Luth A.s telah ada kaum Sodom yang melakukan perbuatan keji ini, yakni melampiaskan nafsunya kepada sesama laki-laki, bukan kepada perempuan. LGBT dalam perspektif al-Qur'an, yang termaktub dalam surat Al-A'raf ayat 80-81 adalah merupakan perbuatan yang fahisyah yang wajib kita hindari. Bahkan Allah juga menurunkan adzab bagi pelaku fahisyah 
tersebut. Dalam Islam, istilah homoseksual dikenal dengan liwath yang artinya melekatkan. Sedang lesbian dikenal dengan sebutan sihaq dan transgender dikenal dengan taghyir al-jins, dan semua perbuatan ini adalah haram. Bagi orang yang melakukan perbuatan fahisyah ini halal darahnya, sabda Rosulullah Saw. : yang artinya "Barang siapa orang yang menjumpai berbuat homoseks seperti praktek kaum Luth, maka bunuhlah si pelaku dan yang diperlakukan (pasangannya)" Di dalam Islam juga terdapat istilah HAM yang terdiri dari al Ushulul Khamsah (pokok-pokok yang lima) yaitu hurriyatud din, hifdzun nafs, hifdzun nasl, hifdzun 'aql, hifdzul mal. Salah satunya adalah hifdzun nasl yang berarti menjaga keturunan, sehingga perbuatan LGBT ini benar-benar tidak diperbolehkan.

LGBT dalam pandangan umum, dapat ditarik kesimpulan sebagai berikut : Lesbian adalah istilah bagi perempuan yang mengarahkan orientasi seksualnya kepada sesama perempuan. Gay adalah istilah untuk laki-laki yang mengarahkan orientasi seksualnya kepada sesama laki-laki yang mencintai laki-laki baik secara fisik, seksual, emosional, atau secara spiritual Biseksualitas adalah seseorang baik perempuan maupun laki-laki yang mempunyai ketertarikan seksual terhadap laki-laki sekaligus perempuan dalam waktu yang bersamaan. Transgender merupakan kondisi dimana sesorang menghayati dirinya dengan gender tertentu, belawanan dengan seks dan biologisnya. Ada dua jenis transgender yaitu male-to-female (MTF) atau yang lebih dikenal dengan transwoman dan female-to-male yang lebih dikenal dengan transman. 


\section{DAFTAR PUSTAKA}

Aibak, Kutbuddin, Kajian Fiqh Kontemporer, Yogyakarta:Teras, 2009.

Al-Farmawi, Abdul Hany, terjemah Rosihon Anwar, Metode Tafsir Maudhu'I, Bandung: Pustaka Setia, 2002.

Al-Juzairi, Abdurrahman, Kitab al-Fiqh 'alaal-Mazahib al-Arba'ah, V, Beirut-Libanon: Ahya al-Tardisu al-Arabi.

Ali Hasan, Masail Fiqhiyah al- Haditsah, Jakarta: Rajawali Pers.

Anang Harris Himawan, Bukan Salah Tuhan Mengazab, Ketika Perzinaan Menjadi Berhala Kehidupan, Penerbit: Tiga Serangkai, Cet.1-Solo, 2007.

Appiyah, K. A, The Ethics of Identity, Princeton, New Jersey : Princeton University Press, 2001.

Audah, Qadir, al-Tasyri' al-Jina 'Ial-IslamiMuqaranah bi al-Qanun al-Wad'i, Iskandariah: Dar al-Nasyr al-Saqafiyah, 1949.

Bahrawi , Mohammad Monib Islah, Islam Dan Hak Asasi Manusia Dalam Pandangan Nur Cholish Madjid, Jakarta: Gramedia, 2011.

Baidhan, Nashruddin, Metodologi Penafsiran Al-Qur'an, Yogjakarta: Pustaka Pelajar, 2005.

Benthem, J, Anarchical Fallacies: A Critical Exammnation of The Declaration of Right, In P. Hayden, 2001, The Philosophy of Human Right, St Paul : Paragon House, 1838-1843.

Boellstorff, Tom, BAB 2 The Gay Archipelago: seksualitas dan bangsa diIndonesia, Inggris:Princeton University Press, 1969.

Budi, Hardiman, Hak-hak Asasi Manusia Polemic dengan Agama dan Kebudayaan, Yogyakarta: Kanisius, 2011.

Davidson, Scot, terj PT Pustaka Utama Grafiti, judul asli Human Rights, Hak Asasi Manusia Sejarah Teori dan Praktek dalam Pergaulan Internasional, Jakarta: PT Utama Grafiti, 2008.

Hasbiyatlah, Masail Fiqhiyah, Jakarta: DirJen Pendidikan Islam, Depag Republik Indonesia, 2009.

Hayden, P, The philosophy of Human right, St Pul : Paragon House, 2001.

Hobbes, T, Leviathan, In P. Hayden, 2001, The philosophy of Human right, St Pul : Paragon House, 1651.

Jurnal Ilmu Syari'ah dan Hukum Vol. 46 No. I, Januari-Juni 2012

16| Neny Muthi'atul Awwaliyah 
Katsir, Ibnu, Tafsir Al Qur'an Al 'Adzim, Istambul: Dar Dakwah

Khalil, H. Munawar, Al-Qur'an dari Masa ke Masa, Cet. I; Semarang: Ramdhani, 1998.

Locke, J, The Second Treatise of Government, In P. Hayden, 2001, The philosophy of Human right, St Pul : Paragon House, 1690.

Mutahhari, Murtadha, Manusia dan Agama, Bandung: Mizan, 1984.

Nadj, Shobirin, Diseminasi Hak Asasi Manusia; Prespektif dan Aksi, Yogyakarta: LKIS, 2000.

Nasution, Adnan Buyung, HAM dalam Agama dan Dialog Antar Peradaban, Paramadina, 1996.

Okdinata, Religiusnitas kaum homoseks, UIN Sunan Kalijaga Yogjakarta, 2009.

Oetomo, Dede, Memberi Suara Pada Yang Bisu, Yogyakarta : Galang Press, 2001.

Quthub, Sayyid, Hazaal-Din, Penerj. Suwito Suproyogi, Inilah Dienul Islam, Jakarta: Media Da'wah, 1987.

Rahman, Penjelasan Lengkap Hukum-hukum Allah (Syariah), Jakarta:RajaGrafindo, 2002.

Rangkuti, Ramlan Yusuf, Homoseksual Jurnal Ilmu Syari'ah dan Hukum, 2012.

Rocky G, Hak Asasi Manusia : teori, Hukum, Kasus, Depok: Filsafat-UI Press, 2006.

Sabiq, Sayyid, Fiqh al-Sunnah, VI , Libanon: Dar al-Fikr, 1968.

Shapiro, I, 2006, Evolusi Hak dalam Teori Liberal (Masri Maris, Penerjemah), Jakarta : Freedom Institute, 2006.

Shihab, M.Quraish, Tafsir al-Mishbah, Pesan, Kesan dan Keserasian alQur'an, Jakarta: Lentera Hati, 2005.

Syalthut, Mahmud, al-Islam Aqidatun wa Syari'atun, Mesir: Dar al-Qalam, 1968.

Triawan, Rido, Jalan Panjang Mencari Keadilan Bagi Kelompok LGBT, Jakarta: Arus Pelangi, 2008. 